\title{
Bacillus subtilis CodY represses early-stationary-phase genes by sensing GTP levels
}

\author{
Manoja Ratnayake-Lecamwasam, Pascale Serror, ${ }^{1}$ Ka-Wing Wong, and Abraham L. Sonenshein ${ }^{2}$ \\ Tufts University School of Medicine, Department of Molecular Biology and Microbiology, \\ Boston, Massachusetts 02111, USA
}

CodY, a highly conserved protein in the low G + C, gram-positive bacteria, regulates the expression of many Bacillus subtilis genes that are induced as cells make the transition from rapid exponential growth to stationary phase and sporulation. This transition has been associated with a transient drop in the intracellular pool of GTP. Many stationary-phase genes are also induced during exponential-growth phase by treatment of cells with decoyinine, a GMP synthetase inhibitor. The effect of decoyinine on an early-stationary-phase gene is shown here to be mediated through CodY and to reflect a reduction in guanine nucleotide accumulation. CodY proved to bind GTP in vitro. Moreover, CodY-mediated repression of target promoters was dependent on a high concentration of GTP, comparable to that found in rapidly growing exponential-phase cells. Because a codY-null mutant was able to sporulate under conditions of nutrient excess, CodY also appears to be a critical factor that normally prevents sporulation under such conditions. Thus, $B$. subtilis CodY is a novel GTP-binding protein that senses the intracellular GTP concentration as an indicator of nutritional conditions and regulates the transcription of early-stationary-phase and sporulation genes, allowing the cell to adapt to nutrient limitation.

[Key Words: CodY; GTP; decoyinine; sporulation; amino acid repression]

Received December 15, 2000; revised version accepted March 13, 2001.

Our understanding of the relationship between environmental signals and global changes in gene expression is limited by the difficulty in identifying intracellular signaling molecules that interact with key regulatory proteins. This gap is particularly apparent for cases of general nutrient limitation. When Bacillus subtilis cells encounter nutrient limitation and enter stationary phase, a variety of adaptive processes-such as genetic competence, secretion of macromolecule-degrading enzymes, import of secondary nutrients, activation of metabolic pathways, chemotaxis and motility, production of antibiotics, and sporulation-are initiated (Sonenshein 1989). A network of global regulatory proteins modulates the cell's response and regulates the choice between adaptation to poor growth conditions and sporulation (Sonenshein 1989, 2000; Burkholder and Grossman 2000), but the specific signals to which these regulators respond have remained a mystery.

Many B. subtilis genes that are expressed early in stationary phase are repressed by CodY (Table 1). Prelimi-

\footnotetext{
1 Present address: Laboratoire de Génétique Microbienne, Institut National de la Recherche Agronomique, 78350 Jouy en Josas, France.

${ }^{2}$ Correseponding author.

E-MAIL linc.sonenshein@tufts.edu; FAX (617) 636-0337.

Article and publication are at www.genesdev.org/cgi/doi/10.1101/ gad.874201.
}

nary results indicate that CodY also contributes to regulation of at least two genes (citB, spoOA) whose products are necessary for sporulation (M. Ratnayake-Lecamwasam and A.L. Sonenshein, unpubl.). Genome sequencing has revealed CodY homologs in Bacillus anthracis, Bacillus halodurans, Bacillus stearothermophilus, Clostridium acetobutylicum, Clostridium difficile, Enterococcus faecalis, Staphylococcus aureus, Streptococcus mutans, Streptococcus pneumoniae, Streptococcus pyogenes, and Lactococcus lactis (www.ncbi.nlm.nih.gov/ Microb_blast/unfinishedgenome.html; Bolotin et al. 1999).

CodY was first identified as a repressor of the B. subtilis dipeptide transport ( $d p p$ ) operon and was found to be active when cells are grown with an excess of glucose or Casamino acids (CAA) as reported by Slack et al. (1995). During vegetative growth, the $d p p$ operon is also directly repressed by AbrB, a second global regulator of earlystationary-phase genes (Slack et al. 1991; Strauch 1993; Serror and Sonenshein 1996b), but the repressive effects of nutrient excess are mediated through CodY, not AbrB (Slack et al. 1993, 1995). CodY also mediates amino acid repression of the $B$. subtilis hut, srfA, ure $A B C$, and hag operons and the comK and gabP genes (Ferson et al. 1996; Fisher et al. 1996; Serror and Sonenshein 1996b; Wray et al. 1997; Mirel et al. 2000) and the L. lactis орp-pepO1, pepN, and pepC genes (Guédon et al. 2001) 
Table 1. Promoters regulated by CodY

\begin{tabular}{|c|c|c|c|}
\hline Target promoters & Function of gene product & $\begin{array}{l}\text { Induced by } \\
\text { decoyinine }\end{array}$ & References \\
\hline \multicolumn{4}{|l|}{ Transport } \\
\hline$d p p$ & dipeptide transport & + & Mathiopoulos et al. 1991; Slack et al. 1995 \\
\hline$g a b P$ & $\gamma$-aminobutyrate transport & ND & Ferson et al. 1996 \\
\hline \multicolumn{4}{|l|}{ Metabolism } \\
\hline hut & histidine degradation & ND & Slack et al. 1995; Fisher et al. 1996 \\
\hline$b k d$ & branched chain aa degradation & ND & Debarbouille et al. 1999 \\
\hline $\operatorname{cit} B$ & aconitase & + & See below \\
\hline ure & urea degradation & ND & Wray et al. 1997 \\
\hline \multicolumn{4}{|l|}{ Chemotaxis/motility } \\
\hline hag & flagellin & ND & Mirel et al. 2000 \\
\hline \multicolumn{4}{|l|}{ Competence/antibiotics } \\
\hline $\operatorname{srf} A$ & surfactin synthesis & + & $\begin{array}{l}\text { Serror and Sonenshein 1996b; } \\
\quad \text { Lazazzera et al. } 1999\end{array}$ \\
\hline $\operatorname{comK}$ & genetic competition & ND & Serror and Sonenshein 1996b \\
\hline \multicolumn{4}{|l|}{ Regulation } \\
\hline $\operatorname{codVWXY}$ & & ND & $\begin{array}{l}\text { Ratnayake-Lecamwasam and } \\
\text { Sonenshein, unpubl. }\end{array}$ \\
\hline $\operatorname{rap} A$ & SpoOF P phosphatase & + & Mueller et al. 1992; Lazazzera et al. 1999 \\
\hline rapC & ComA P phosphatase & ND & Lazazzera et al. 1999 \\
\hline \multicolumn{4}{|l|}{ Sporulation } \\
\hline$c i t B$ & aconitase & + & $\begin{array}{l}\text { Dingman et al. 1987; Ratnayake-Lecamwasam } \\
\text { and Sonenshein, unpubl. }\end{array}$ \\
\hline spoOA (sporulation promoter) & transcription factor & ND & Ratnayake-Lecamwasam and Sonenshein, unpubl. \\
\hline
\end{tabular}

In this work, we sought to identify the signal that indicates nutrient excess or limitation and thereby regulates CodY activity.

Although CodY might sense the intracellular concentration of one or more amino acids, its activity might also be regulated, as Wray et al. (1997) have suggested, by the decrease in growth rate that is observed when $B$. subtilis cells encounter nutrient-limiting conditions. When bacterial growth rate drops, due to carbon source or amino acid limitation, the stringent response is activated, leading to conversion of GTP to pppGpp and ppGpp (Cashel et al. 1996), and biosynthesis is attenuated. Thus, accumulation of (p)ppGpp or a decrease in GTP might be the signal that inactivates CodY and derepresses CodY-regulated genes.

It is, in fact, well-established that B. subtilis cells, as they enter stationary phase, undergo a transient decrease in their GDP and GTP pools (Mitani et al. 1977; Freese et al. 1979a; Lopez et al. 1979), which may be due either to conversion of GTP to (p)ppGpp or to the depletion of precursors necessary for guanine nucleotide synthesis (Mitani et al. 1977; Freese et al. 1979a; Lopez et al. 1979; Ochi et al. 1981; Mathiopoulos et al. 1991; Sonenshein 2000). A forced reduction in guanine nucleotide pools by treatment of cells with decoyinine, an inhibitor of GMP synthetase (Lopez et al. 1979), also induces stationary phase genes (Table 1).

In this study, we show that the decoyinine-dependent derepression of $d p p$ is mediated through CodY. We further show that CodY is a GTP-binding protein and that CodY-mediated repression of the $d p p$ promoter is dependent in vitro on a high concentration of GTP, comparable to that found in rapidly growing exponential-phase cells. Our results also indicate that CodY is a critical factor that prevents the initiation of sporulation under conditions of nutrient excess.

\section{Results}

\section{CodY concentration during exponential-growth} and stationary phase

In $B$. subtilis cells grown in nutrient broth sporulation (DS) medium, CodY-regulated genes are repressed during exponential-growth phase and induced at the entry into stationary phase. To determine whether expression of these genes correlates with the presence or absence of CodY protein, cultures of wild-type (PS29) and $\Delta \operatorname{codY}$ (PS37) mutant strains in DS medium were sampled at various times during growth. Proteins released by sonication were analyzed by Western blotting, using a serum polyclonal antibody to CodY. Figure $1 \mathrm{~A}$ indicates that during both exponential-growth and stationary phase, the CodY concentration of the wild-type B. subtilis strain remained about the same. Even $8 \mathrm{~h}$ after the onset of stationary phase, the CodY concentration was similar to that in exponential-phase cells (results not shown). The codY-null strain, as expected, did not contain any protein that reacted with the antibody. When the wildtype strain was grown in S7, a defined medium containing $0.5 \%$ glucose, the concentration of CodY again did not change significantly, irrespective of the presence or absence of $0.1 \%$ CAA (Fig. 1B). In S7 medium, the presence of glucose and CAA strongly inhibits expression of CodY-regulated genes (Serror and Sonenshein 1996b). These results indicate that the presence of CodY is not 
A

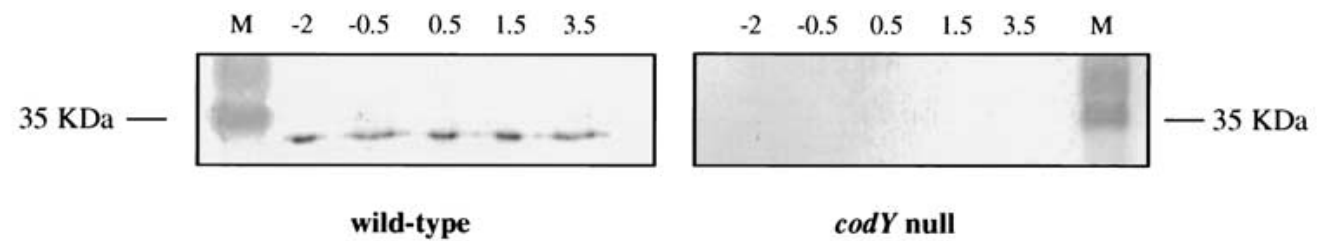

B
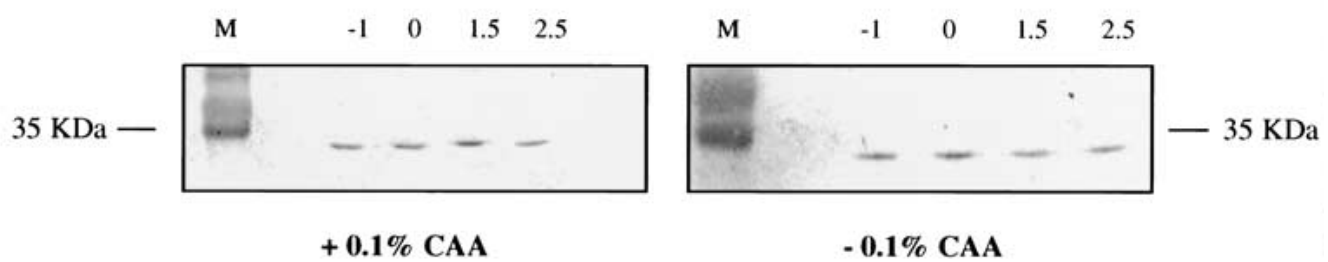

Figure 1. CodY concentration during exponential growth and stationary phase. Samples were taken at the indicated time points (in h) before and after entry into stationary phase $\left(T_{0}\right)$ and proteins of each crude lysate were separated by SDS-PAGE. The proteins were electrotransferred and immunoblotted with a polyclonal CodY antibody. Lane $M$ contains prestained molecular weight markers (GIBCO-BRL). (A) Immunoblots of lysates from wild-type and $\Delta c o d Y$ strains grown in DS medium. (B) Immunoblots of lysates from a wild-type strain grown in $\mathrm{S} 6$ medium in the presence $(\mathrm{S} 6 \mathrm{C})$ or absence $(\mathrm{S} 6)$ of $0.1 \%$ CAA.

affected by the growth phase or by the composition of the medium, that is, by conditions that affect expression of CodY-regulated genes.

\section{The target of decoyinine}

Mathiopoulos et al. (1991) found that $d p p$ expression in $B$. subtilis cells growing rapidly under conditions of nutrient excess is derepressed $\sim 8 \mathrm{~min}$ after the addition of decoyinine, a GMP synthetase inhibitor. Two proteins, $\mathrm{AbrB}$ and CodY, are known to regulate $d p p$ expression (Slack et al. 1995). To see which, if either, of these proteins is the target of decoyinine, $d p p$ expression was studied in decoyinine-treated wild-type, $\operatorname{abr} B, \Delta \operatorname{cod} Y$, and $a b r B \Delta c o d Y$ strains. The addition of decoyinine to strains PS59 (WT) and PS56 (abrB) had the same effect; $d p p$ expression was derepressed rapidly (Fig. 2A). However, in PS164 $(\Delta \operatorname{cod} Y)$ cells, in which $d p p$ expression is partially derepressed during exponential phase, no additional derepression of $d p p$ expression was observed after the addition of decoyinine (Fig. 2B). Decoyinine also had no added effect on $d p p$ expression in PS83 $(a b r B \Delta c o d Y)$ cells in which $d p p$ expression is derepressed to the highest level seen under any condition. These results show that the decoyinine effect on $d p p$ expression is not mediated through $\mathrm{AbrB}$ or another unidentified regulator of $d p p$ and imply strongly that CodY is the direct or indirect target of decoyinine.

B. subtilis cells can take up exogenous guanosine from the culture medium and convert it via the salvage pathway to GMP, GDP, and GTP (Nygaard 1993), bypassing the metabolic block caused by decoyinine. When B. subtilis wild-type strain PS59 was grown in S6C medium supplemented with $1 \mathrm{mM}$ guanosine, the addition of decoyinine failed to induce $d p p$ expression (Fig. 2C). Thus, $d p p$ expression and, by extension, CodY respond directly or indirectly to guanine nucleotide levels.
Effect of decoyinine on dpp expression

in $a \mathrm{~B}$. subtilis relA strain

The relA gene encodes the only (p)ppGpp synthetase in B. subtilis (Lopez et al. 1981; Wendrich and Marahiel 1997). Partial amino acid limitation, leading to an increase in (p)ppGpp and a reduction in GTP levels, induces spore formation in relA ${ }^{+}$cells but not in relAmutant cells (Lopez et al. 1981; Ochi et al. 1981). Although a relA-mutant strain sporulates poorly (Lopez et al. 1981; Eymann et al. 2001), such a strain can be made to sporulate by adding decoyinine (Ochi et al. 1981). We have found that activation of the stringent response also induces the dpp operon (Ratnayake-Lecamwasam 2001).

To see if derepression of CodY-regulated genes is dependent on synthesis of (p)ppGpp under all conditions, decoyinine was added to rapidly growing cells of a $B$. subtilis strain carrying a relA mutation. In wild-type cells, $d p p$ expression reached its maximal level $30 \mathrm{~min}$ after the addition of decoyinine (Fig. 3A). In relA cells, $d p p$ expression was derepressed to the same extent within 45 min after decoyinine addition (Fig. 3B). In control cells that had not been treated with decoyinine, $d p p$ expression increased at the point of transition from exponential-growth to stationary phase even in relA mutant cells (Fig. 3B). Thus, the stringent response is not essential for decoyinine-mediated and stationary-phasedependent derepression of $d p p$ expression.

\section{Effect of decoyinine on sporulation of wild-type and $\Delta$ codY strains}

Wild-type B. subtilis cells sporulate very poorly in S6 medium supplemented with $0.1 \%$ CAA and $0.5 \%$ glucose $(\mathrm{S} 6 \mathrm{C})$ but sporulate quite well in this medium when decoyinine is added (Freese et al. 1979b). As Table 2 indicates, treatment with decoyinine increased spore production of PS59 (wild-type) cells by nearly 200 -fold. In- 

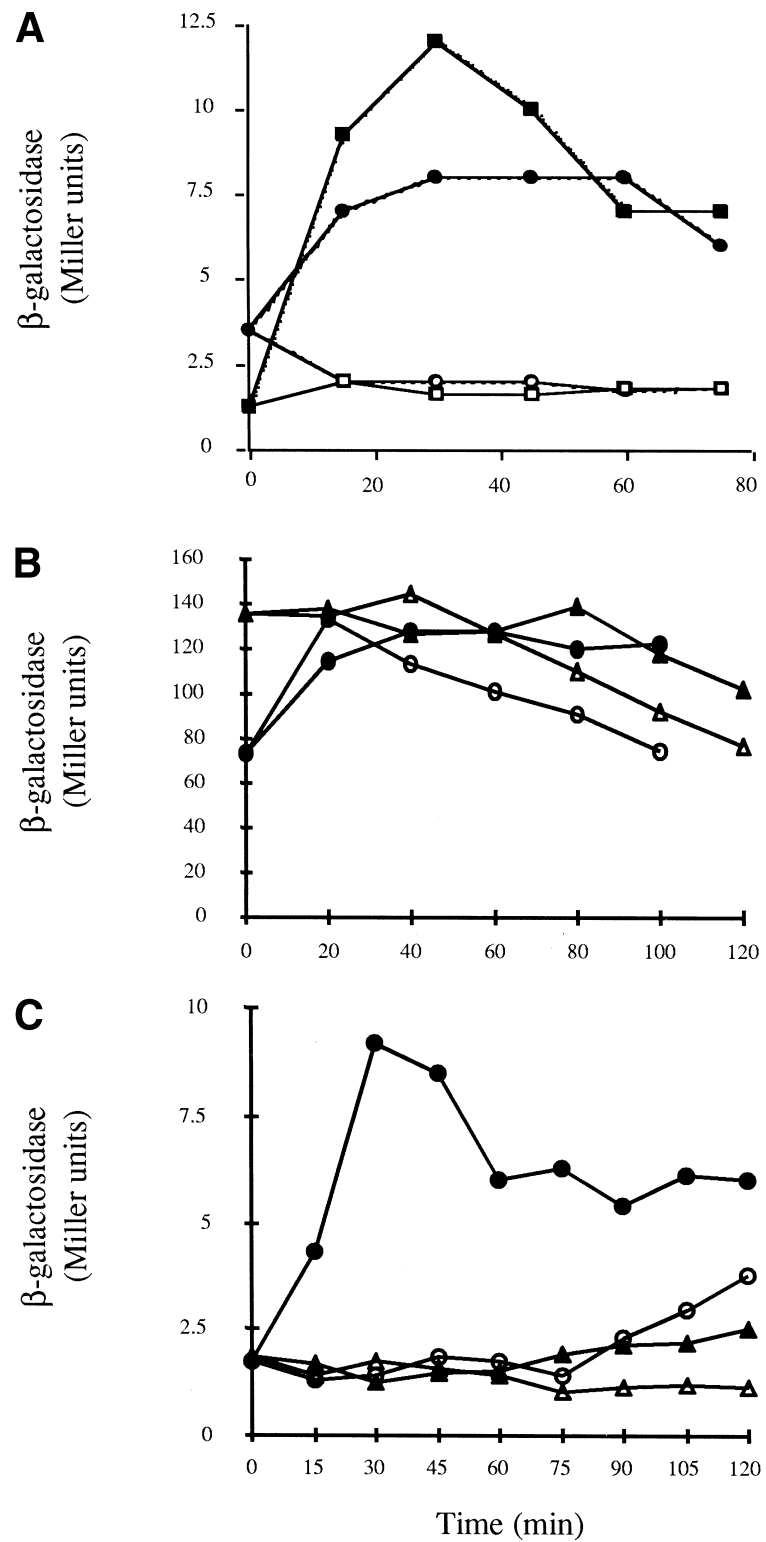

Figure 2. The effect of decoyinine on $d p p-l a c Z$ directed $\beta$-galactosidase expression in cells grown in S6C medium. When the cultures reached a turbidity at $600 \mathrm{~nm}$ of 0.3 to $0.4\left(\mathrm{~T}_{0}\right.$ for this experiment), the cultures were split into two 25-ml cultures and $0.125 \mathrm{ml}$ of either $1 \mathrm{~N} \mathrm{KOH}$ (open symbols) or decoyinine (100 $\mathrm{mg} / \mathrm{mL}$ in $1 \mathrm{~N} \mathrm{KOH}$ ) was added (closed symbols). (A) Strains PS59 $\left(a b r B^{+} \operatorname{cod} Y^{+}\right)$, squares; PS56 $\left(a b r B \operatorname{cod} Y^{+}\right)$, circles. $(B)$ Strains PS164 ( $\left.a b r B^{+} \operatorname{cod} Y\right)$, circles; PS83 (abrB cod $\left.Y\right)$, triangles. (C) Strain PS59 was grown in the presence or absence of $1 \mathrm{mM}$ guanosine. Triangles, $\beta$-galactosidase activity in the presence of guanosine; circles, in the absence of guanosine. The experiments were performed in duplicate and any variations in data points were $<10 \%$ of the represented values.

terestingly, the PS164 ( $\Delta \operatorname{cod} Y)$ strain formed 400 times more spores than did PS59 in S6C medium. The addition of decoyinine to PS164 cells led to a slight decrease in sporulation. Because the sporulation defect of $B$. subtilis cells grown in $\mathrm{S} 6 \mathrm{C}$ medium is overcome by a mutation in $\operatorname{cod} Y$ or by a decrease in guanine nucleotide synthesis, CodY appears to be an important guanine nucleotide sensor or a component of a sensory pathway for regulation of sporulation in this medium.

\section{GTP-binding motifs in CodY}

Small GTPases have conserved G1 (A/GX $\left.\mathrm{GKKT}_{4} \mathrm{~S}\right)$, G3 $\left(\mathrm{DX}_{2} \mathrm{G}\right)$, and $\mathrm{G} 4$ (T/NKXD) GTP-binding motifs. A putative G1 motif (GGERLGTL) was found in CodY between amino acids 119 and 126, a putative G3 motif (DRVG) between amino acids 208 and 211, and a putative G4 motif (NKFL) between amino acids 247 and 250. Unlike the G1 consensus sequence, the CodY G1-like motif does not contain a lysine residue at the seventh position. The CodY G3 overlaps the HTH domain of CodY, spanning the last three amino acids of helix I (Asp, Arg, and Val) and the first amino acid of the turn (Gly). The CodY G4 motif varies from the consensus at the fourth position, where in CodY, leucine is substituted for aspartate. These putative GTP-binding motifs are also present in CodY homologs identified by sequence analysis in other gram-positive bacteria (Table 3).

\section{Binding of purine nucleotides to CodY}

To determine if CodY interacts directly with GTP, a mixture of CodY (overexpressed in and purified from $E$. coli; Serror and Sonenshein 1996a) and $\left[\alpha{ }^{32} \mathrm{P}\right]$ GTP was tested for UV-induced cross-linking (Fig. 4A). Two radioactive bands were seen; the larger was a full-length CodY protein $(\sim 30 \mathrm{kD})$ and the smaller $(20-25 \mathrm{kD})$ was a truncated form of CodY (as identified by immunoblotting with the CodY antibody) that most likely resulted from degradation during purification. CodY-His ${ }_{6}$ (see Materials and Methods) purified from B. subtilis could also be cross-linked to $\left[\alpha-{ }^{32} \mathrm{P}\right]$ GTP (data not shown). The formation of the cross-linked, radioactive GTP-CodY complexes was inhibited when excess unlabelled GTP was present (Fig. 4). We found that CodY-His ${ }_{6}$ could also be cross-linked to $\left[\alpha^{-32} \mathrm{P}\right]$ ATP (data not shown). These results show that CodY interacts directly with purine nucleotides.

To test the specificity of GTP binding to CodY, we performed UV-mediated cross-linking experiments with $0.1 \mathrm{mM}\left[\alpha-{ }^{32} \mathrm{P}\right] \mathrm{GTP}$ in the presence of unlabelled GTP, ATP, CTP, or UTP. As expected, $0.5 \mathrm{mM}$ unlabelled GTP reduced the $\left[\alpha-{ }^{32} \mathrm{P}\right]$ GTP bound to CodY by $85 \%$ (Fig. 4B). Competition experiments with other unlabelled nucleoside triphosphates showed that CodY binds more tightly to GTP than to the other NTPs but that the affinity for ATP is higher than that observed for pyrimidine nucleotides.

\section{Effect of GTP on repression by CodY}

Gel mobility-shift and DNase I footprinting assays showed that CodY binds to the dpp, srfA, and $\operatorname{comK}$ promoters in the absence of added GTP (Serror and 

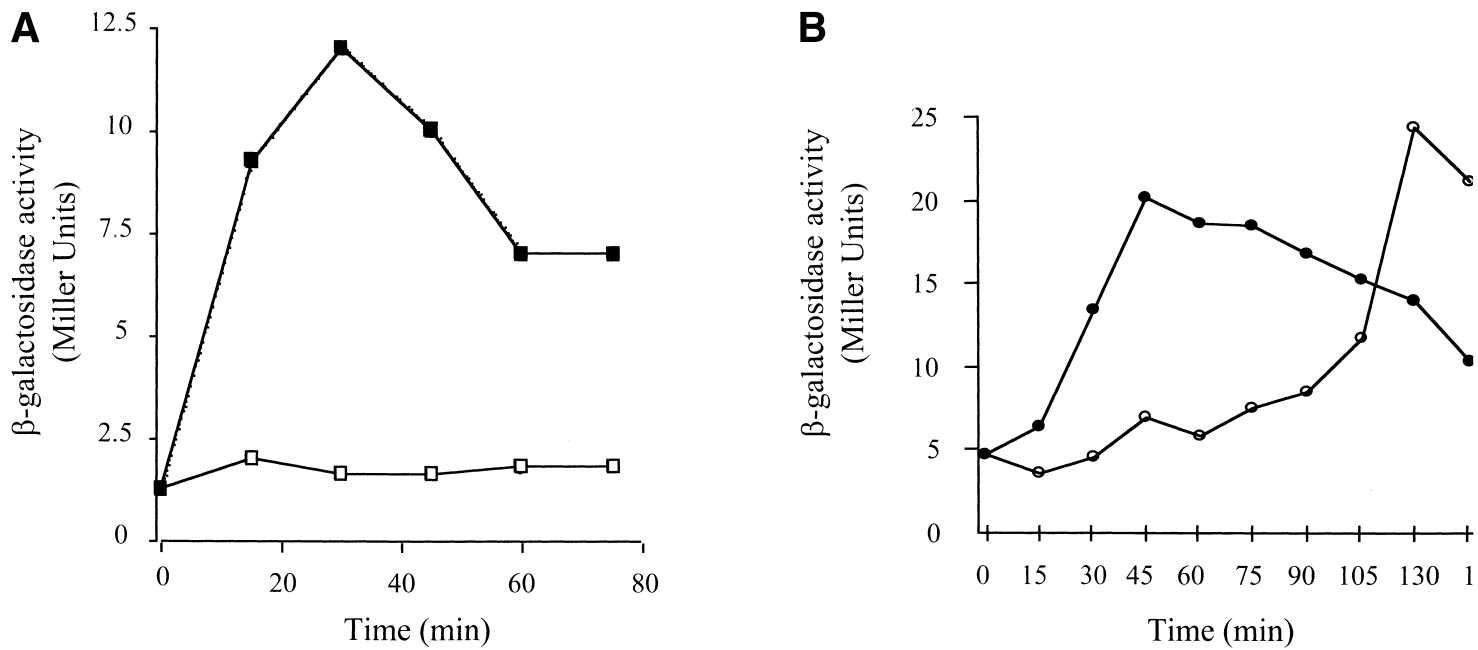

Figure 3. Effect of a relA mutation on induction of $d p p-l a c Z$ by decoyinine. When cultures in S6C medium reached a turbidity at 600 $\mathrm{nm}$ of 0.3 to $0.4\left(\mathrm{~T}_{0}\right)$, the cultures were split into two $25-\mathrm{ml}$ cultures and $0.125 \mathrm{ml}$ of either $1 \mathrm{~N} \mathrm{KOH}$ (open symbols) or decoyinine (100 $\mathrm{mg} / \mathrm{mL}$ in $1 \mathrm{~N} \mathrm{KOH}$; closed symbols) was added. $(A)$ Strain PS59 $\left(\text { relA }{ }^{+}\right)_{;}(B)$ Strain MRLB10 (relA). The experiments were performed in duplicate and any variations in data points were $<15 \%$ of the represented values.

Sonenshein 1996a,b). When GTP was added to $2 \mathrm{mM}$, the apparent affinity of CodY for the $d p p$ and $\operatorname{srf} A$ promoter regions increased only three- to fourfold (data not shown). To test whether CodY represses transcription directly and whether GTP has a greater effect on repression than on DNA binding, we performed in vitro transcription experiments, initiating at the $d p p$ promoter as described in Materials and Methods. Figure 5 shows that a transcript of the expected size (155 nt) was obtained in the absence of CodY (panel $A$, lane 1) and that the addition of CodY-His ${ }_{6}$ had little or no effect on the production of this transcript (panel $A$, lane 2). Unmodified CodY purified after overexpression in E. coli also failed to repress $d p p$ transcription in vitro (data not shown). Thus, CodY is either not a direct repressor of $d p p$ or requires an effector in order to repress transcription.

Table 2. Effect of a $\Delta$ codY mutation on sporulation under nutrient excess conditions

\begin{tabular}{lcccc}
\hline Strain & $\begin{array}{c}\text { Decoyinine } \\
\text { addition }\end{array}$ & $\begin{array}{c}\text { Viable } \\
\text { cells } \\
(\mathrm{cfu} / \mathrm{mL})\end{array}$ & $\begin{array}{c}\text { Spores }^{\star} \\
(\mathrm{cfu} / \mathrm{mL})\end{array}$ & $\begin{array}{c}\text { (Spores/viable } \\
\text { cells }) \\
\times 100(\%)\end{array}$ \\
\hline Wild-type & - & $8.75 \times 10^{7}$ & $1.5 \times 10^{5}$ & 0.15 \\
Wild-type & + & $8.25 \times 10^{7}$ & $2.6 \times 10^{7}$ & 31 \\
$\Delta \operatorname{cod} Y$ & - & $7.40 \times 10^{7}$ & $6.7 \times 10^{7}$ & 91 \\
$\Delta \operatorname{cod} Y$ & + & $6.50 \times 10^{7}$ & $3.7 \times 10^{7}$ & 58 \\
\hline
\end{tabular}

Bacillus subtilis wild-type (PS59) and $\Delta \operatorname{codY}$ (PS164) strains were grown in S6C medium. When the cultures reached a turbidity at $600 \mathrm{~nm}$ of 0.3 to 0.4 , they were split. One subculture received decoyinine dissolved in $\mathrm{KOH}$, and the other $\mathrm{KOH}$ only (see Materials and Methods). After further incubation for $\sim 20 \mathrm{~h}$, a sample of each culture was serially diluted; each dilution was divided in half, and one half was incubated at $80^{\circ} \mathrm{C}$ for $10 \mathrm{~min}$. The heat-treated and unheated cells were plated on DS medium and the mean values for viable cells and spores were calculated. * The values in each column are the average of two independent experiments.
To test whether GTP is the co-repressor for CodY, we performed in vitro transcription reactions with the $d p p$ promoter in the presence of purified CodY-His ${ }_{6}$ and GTP at concentrations ranging from $0.2 \mathrm{mM}$ to $2.2 \mathrm{mM}$. As shown in Figure 5 (panels $C, D$ ) $d p p$ transcription was inhibited in reactions that contained CodY and a high

Table 3. Comparison of putative GTP binding motifs in CodY homologs

\begin{tabular}{|c|c|c|c|}
\hline \multirow{3}{*}{$\begin{array}{l}\text { Small GTPases } \\
\text { Consensus sequences }\end{array}$} & \multirow{2}{*}{$\begin{array}{c}\text { G1 } \\
\text { GXXXXGXT }\end{array}$} & \multirow{3}{*}{$\begin{array}{c}\text { G3 } \\
\text { DXXG }\end{array}$} & \multirow{3}{*}{$\begin{array}{l}\text { G4 } \\
\text { NKXD } \\
\text { TQ }\end{array}$} \\
\hline & & & \\
\hline & A $\quad$ S & & \\
\hline \multicolumn{4}{|l|}{ FtsZ } \\
\hline E. coli & LGGGTGTG & $\mathrm{DAFG}$ & TSLD \\
\hline \multicolumn{4}{|l|}{ CodY } \\
\hline B. subtilis & GGERLGTL & DRVG & NKFL \\
\hline B. stearothermophilus & GGERLGTL & DRVG & DKFL \\
\hline B. halodurans & GGQRLGTL & DRVG & DKFL \\
\hline B. anthracis & GGERLGTL & $\mathrm{NA}^{\mathrm{a}}$ & $\mathrm{NA}^{\mathrm{a}}$ \\
\hline C. difficile & GGMRLGSL & DRIG & NEGI \\
\hline C. acetobutylicum & NRERLGTL & DRVG & ILND \\
\hline S. pneumoniae & SGIRLGSL & DRIG & LISD \\
\hline E. faecalis & AGKRLGTI & DRVG & NQQF \\
\hline S. mutans & GGMRLGSL & DRIG & NEGI \\
\hline S. aureus & GGERLGTL & DRIG & EKGI \\
\hline S. pyogenes & GGMRLGSL & DRIG & NEGI \\
\hline L. lactis & SGMRLGTF & DKIG & $\mathbf{T G L F}$ \\
\hline
\end{tabular}

CodY sequences of B. stearothermophilus, B. halodurans, $B$. anthracis, C. difficile, C. acetobutylicum, S. pneumoniae, E. faecalis, S. mutans, S. aureus, and $S$. pyogenes were obtained from http://www.ncbi.nlm.nih.gov/Microb_blast/unfinishedgenome.html, and compared using the BLAST program (Altschuhl et al. 1997). The E. coli FtsZ motifs were from RayChaudhuri and Park (1992), the B. subtilis CodY sequence was from Slack et al. (1995), and L. lactis CodY was from Bolotin et al. (1999). The consensus sequences for G1, G3, and G4 motifs were from Bourne et al. (1991).

${ }^{a}$ Not available. 
A

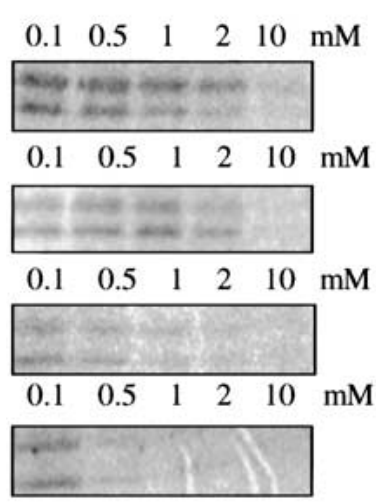

B

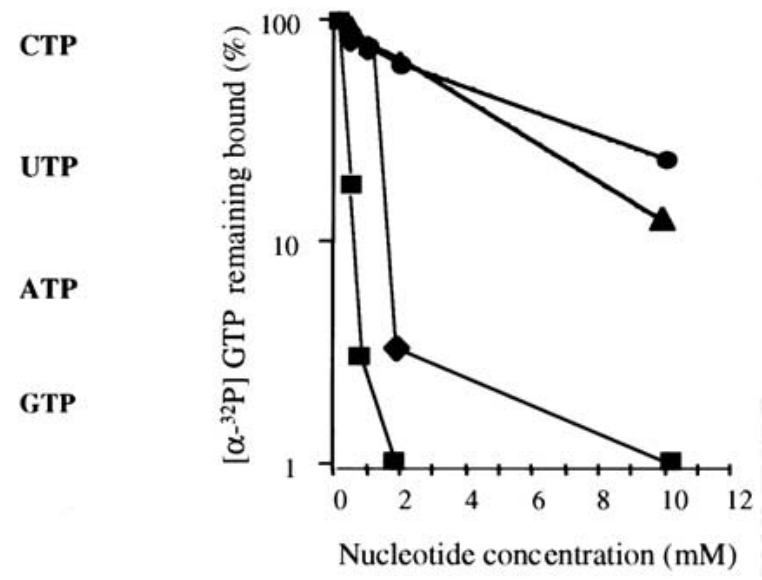

Figure 4. Ultraviolet-induced crosslinking of $\left[\alpha{ }^{32} \mathrm{P}\right] \mathrm{GTP}$ to $\operatorname{CodY}$. $(A) \operatorname{CodY}(3 \mu \mathrm{M})$, overexpressed and purified from Escherichia coli BL21/ $\lambda$ DE3, was incubated with $0.1 \mathrm{mM}\left[\alpha-{ }^{32} \mathrm{P}\right]$ GTP and $0.1,0.5,1,2$, and $10 \mathrm{mM}$ unlabelled GTP, ATP, CTP, or UTP and irradiated with UV light. Irradiated samples were analyzed by SDS-PAGE (12\% polyacrylamide) and exposed to a phosphorimager screen. (B) Quantitation of results in part $(A)$. Unlabelled GTP, closed squares; unlabelled ATP, closed diamonds; unlabelled CTP, closed circles; unlabelled UTP, closed triangles.

concentration of GTP. At $2.2 \mathrm{mM}$ GTP, residual $d p p$ transcription was $20 \%$ (Fig. 5D). In reactions that did not contain CodY, $d p p$ transcription was not inhibited at any concentration of GTP tested (Fig. 5D). Thus, CodY represses transcription from the $d p p$ promoter but only when GTP is present at high concentration. The intracellular concentration of GTP in rapidly growing $B$. subtilis cells has been estimated at 1-3 mM (Lopez et al. 1979; Neidhardt et al. 1990).

Because we found that CodY binds ATP with an affinity similar to that for GTP, we tested whether CodY could repress $d p p$ transcription in the presence of ATP. Even at $2.2 \mathrm{mM}$ ATP, no inhibition of $d p p$ transcription was seen (Fig. 5D). CTP (3.2 mM) was also ineffective as a co-repressor for CodY (data not shown). Additionally, we have shown that ATP $(2.2 \mathrm{mM})$ does not interfere with the effect of GTP $(2.2 \mathrm{mM})$ on CodY-mediated repression of $d p p$ transcription (Fig. 5D). To investigate the specificity of GTP-bound CodY, we studied the in vitro transcription of the veg promoter in the presence of GTP and CodY-His 6 (Fig. 5B). The veg promoter is strongly transcribed during vegetative growth (Le Grice et al. 1986) and is not a known target of CodY. Transcription of the veg promoter was not inhibited by CodY, even in the presence of $2.2 \mathrm{mM}$ GTP.

\section{Discussion}

Our results suggest a mechanism for the effect of nutrient limitation on the expression of stationary-phase and early-sporulation genes in B. subtilis. It appears that CodY bound to GTP represses many stationary-phase and some early-sporulation genes during growth in excess nutrients. The intracellular concentration of GTP is 1-3 $\mathrm{mM}$ in exponential-phase cells grown in rich me- dium (Lopez et al. 1979; Neidhardt et al. 1990). When the GTP concentration is within this range during in vitro transcription, CodY represses the $d p p$ promoter. Under slow-growth conditions or as stationary phase approaches, the GTP level decreases, due to (p)ppGpp production or a reduction in GTP synthesis or both. As a result, CodY is no longer bound to GTP and can no longer repress transcription. Lopez et al. (1979) found that the pool of GTP drops by $70 \%-80 \%$ at the entry into stationary phase. If our in vitro experiments are a faithful reflection of in vivo conditions, such a drop would lead to substantial derepression of CodY-regulated genes. Although GTP activates CodY as a repressor, at least 30 other metabolites tested for stimulation or inhibition of CodY binding and repression in vitro were ineffective (P. Serror and A.L. Sonenshein, unpubl.). The strong conservation of CodY in other gram-positive bacteria suggests that it may have similar functions in these other organisms as well.

Expression of $d p p$ is derepressed in a relA-dependent manner when the stringent response is activated (Ratnayake-Lecamwasam 2001) but can also be derepressed in a relA-independent manner by the addition of decoyinine, a GMP synthetase inhibitor. The stringent response appears to participate in inactivation of CodY in two indirect ways. First, synthesis of $(\mathrm{p}) \mathrm{ppGpp}$ is at the expense of GTP. Second, Freese et al. (1979a) showed that (p)ppGpp inhibits IMP dehydrogenase, the first enzyme of the GMP synthesis pathway. Both effects of the stringent response cause a reduction in the GTP pool. CodY-regulated genes are also expressed during slow exponential growth (Slack et al. 1991; Wray et al. 1997); the stringent response may be an important mechanism for reducing the GTP pool under these conditions.

The role of amino acid mixtures, such as CAA, in pro- 
A

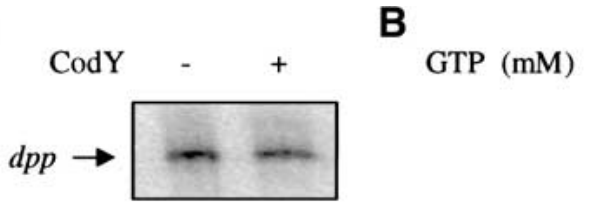

veg promoter
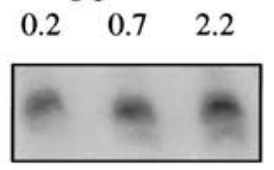

dpp promoter

$\begin{array}{lll}0.2 & 0.7 & 2.2\end{array}$

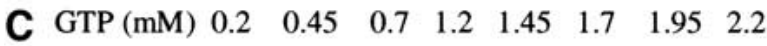

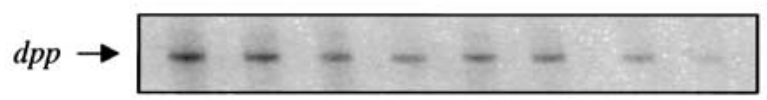

D

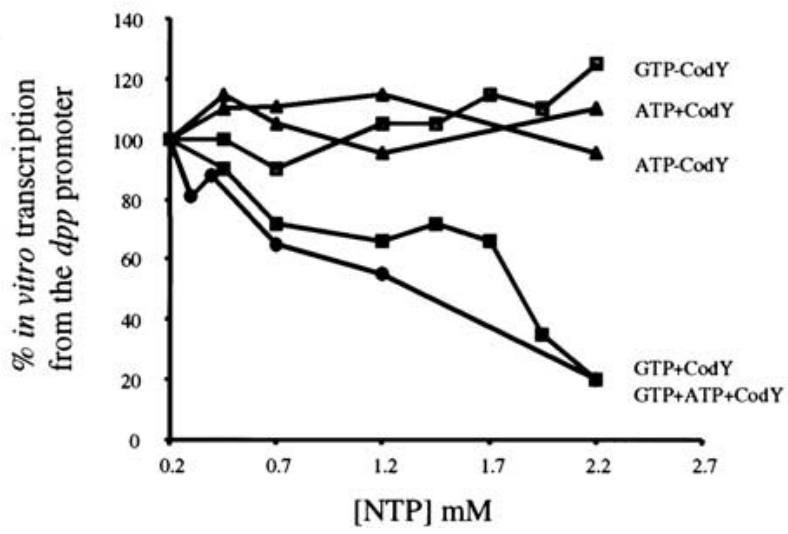

Figure 5. The effects of GTP and ATP on CodY-mediated repression. In vitro transcription reactions were performed with $d p p$ promoter- or veg promoter-containing fragments as the template. The reactions were initiated by adding Bacillus subtilis E $\sigma^{\mathrm{A}} \mathrm{RNA}$ polymerase (see Materials and Methods). The $d p p$ transcript is $155 \mathrm{n}$; the veg transcript is $104 \mathrm{n}$. (A) The $d p p$ promoter fragment (80 $\mathrm{nM})$ was incubated with RNA polymerase $(37 \mathrm{nM})$; CodY-His 6 ( $300 \mathrm{nM})$ was added as indicated. $(B)$ The veg or $d p p$ promoter fragments $(40 \mathrm{nM})$ were incubated with RNA polymerase $(19 \mathrm{nM})$ and CodY-His ${ }_{6}(180 \mathrm{nM})$ in the presence of varying concentrations of GTP. (C) Transcription from the $d p p$ promoter $(80 \mathrm{nM})$ by RNA polymerase $(37 \mathrm{nM})$ in the presence of CodY-His 6 (300 $\mathrm{nM})$ and varying concentrations of GTP. $(D)$ Quantitation of in vitro transcription results. The data from part $(C)$ and from parallel experiments in which the concentrations of ATP or ATP and GTP were varied were analyzed using the ImageQuant program.

voking CodY-dependent repression cannot be fully mimicked by individual amino acids (Atkinson et al. 1990; P. Serror and A.L. Sonenshein, unpubl.). In the case of the dpp operon, only branched-chain amino acids (Val, Ile, and Leu; BCAA), separately or in combination, had a significant stimulating effect on CodY activity (P. Serror, unpubl). Interestingly, in L. lactis, the CodY-dependent repression of genes involved in protein degradation is strongly dependent on the presence of BCAA /Guédon et al. 2001). If $L$. lactis CodY has the same properties as the B. subtilis CodY, the BCAA may act by affecting the intracellular pool of GTP, perhaps via the stringent response.

Although CodY clearly has motifs in common with small GTPases and binds GTP, the highly purified protein has no GTPase activity (data not shown). Small GTPases usually have high affinity for GTP. The low apparent affinity of CodY is consistent, however, with its putative role in sensing intracellular GTP pools. Whereas the activity of the GTPases is modulated by cleavage of bound GTP, activation of CodY depends on the high steady-state concentration of GTP found in rapidly growing exponential-phase cells. The G1 motif of CodY (GGERLGTL) lacks the lysine residue found at the seventh position of the G1 consensus sequence (Table 3). In small GTPases, this conserved lysine has been shown to interact with the $\alpha$ - and $\beta$-phosphates of guanine nucleotides (Saraste et al. 1990; Bourne et al. 1991); its absence may contribute to the low affinity of CodY for GTP. Interestingly, the codY16 mutation changes the conserved glycine in the sixth position of the G1 motif of CodY to asparagine and causes strong derepression of $d p p$ during exponential growth (Slack et al. 1995). Preliminary experiments indicate that the CodY16 protein has a greatly decreased affinity for GTP (D. Negusse and M. Ratnayake-Lecamwasam, unpubl.).

The CodY G3 motif (DRVG) spans the last three residues of helix I and the first residue of the turn of the CodY helix-turn-helix (HTH) motif, which has been previously implicated in DNA-binding (Serror and Sonenshein 1996a). This potential overlap between GTP- and DNA-binding motifs is unusual. Although the presence of GTP has only a small effect on the affinity of CodY for DNA, it is possible that the binding of GTP alters the interaction of CodY with target sites in such a way as to allow it to act as a repressor. Such a model would be formally analogous to the effect of ATP on DnaA protein (Speck et al. 1999).

Expression of CodY-regulated and CodY-independent stationary-phase and early-sporulation genes is also modulated by proteins (e.g., AbrB, SinR, Soj) that are responsive to cell population density signals or other early- 
stationary-phase conditions (Bai et al. 1993; Cervin et al. 1998; Quisel et al. 1999). Moreover, CodY is not the only GTP-binding B. subtilis protein implicated in gene regulation. Obg is an essential protein (Trach and Hoch 1989) required for activation of the SpoOA transcription factor at the onset of sporulation (Kok et al. 1994; Vidwans et al. 1995) and may also be a GTP-sensing regulator of stationary-phase gene expression. However, Obg has not yet been implicated as a direct regulator of sporulation genes in response to GTP availability. Obg also appears to be necessary for the activation of the stress-induced transcription factor $\sigma^{\mathrm{B}}$ (Scott et al. 2000).

Guanine nucleotides may be generally sensed by bacteria as indicators of nutritional sufficiency. In E. coli, growth-rate-dependent control appears to be mediated by the availability of GTP (and ATP), which acts on RNA polymerase at the initiation step of transcription from rRNA promoters (Gaal et al. 1997). In Myxococcus xanthus, conversion of GTP to (p)ppGpp is necessary for differentiation, but the effect is independent of any change in the GTP pool; the requirement for RelA during differentiation in this organism is not bypassed by treatment with decoyinine (Singer and Kaiser 1995).

\section{Materials and methods}

Bacterial strains, plasmids, and growth conditions

The B. subtilis strains used in this study are described in Table 4. Strain KWB1 encoding CodY-His ${ }_{6}$ was constructed as follows: The $3^{\prime}$ region of the CodY gene was amplified by PCR, using $B$. subtilis JH642 chromosomal DNA as the template DNA, with OKW1 (5'GCATGGATCCATACTGCTTTCCCTGTTGAG-3') and OKW3 $\left(5^{\prime}\right.$ CGCGAAGCTTTTAATGATGATGATGAT GATGAGATTTTAGATTTTCTAATTCAATTAGG-3') as upstream and downstream primers, respectively. The OKW3 primer includes a sequence that would add a $6 \times$ His-tag (indicated in boldface) to the C-terminus of CodY. The PCR-amplified DNA was digested with restriction endonucleases BamHI and HindIII (cleavage sites italicized) and ligated (Sambrook et al. 1989) to the BamHI and HindIII-digested pJPM1 vector (Mueller et al. 1992), creating pKW1. Integration of pKW1 into the B. subtilis strain JH642 chromosome by homologous recombination resulted in strain KWB1. CodY-His ${ }_{6}$ was fully functional in vivo as judged by repression of a $d p p P-1 a c Z$ fusion.

\section{Determination of CodY abundance in B. subtilis}

B. subtilis strains were grown in $500 \mathrm{~mL}$ of DS medium (Fouet and Sonenshein 1990) or S7 medium (Freese et al. 1979b) supplemented as indicated with $0.5 \%$ glucose and $0.1 \%$ CAA. At the indicated time points, $35-\mathrm{mL}$ samples were removed; cells were collected by centrifugation, washed with $10 \mathrm{~mL}$ of solution A (Serror and Sonenshein 1996a), and stored overnight at $-80^{\circ} \mathrm{C}$. Cell pellets were suspended in $2 \mathrm{~mL}$ of solution A and subjected to six 30-sec cycles of sonication, with 15 -sec rest periods between cycles. Unbroken cells and cell debris were removed by centrifugation at $13,000 \mathrm{rpm}$ for $15 \mathrm{~min}$ at $4^{\circ} \mathrm{C}$. The total protein concentrations of the supernatant fluids were determined by using the Bio-Rad protein assay reagent, and $10 \mu \mathrm{g}$ of total protein of each sample was analyzed by Western blotting, as described below.

\section{SDS-PAGE and Western blotting}

Protein samples were mixed with an equal volume of $2 \times$ SDSPAGE-loading buffer, boiled for 3 min, loaded on $12 \%$ denaturing polyacrylamide gels, and subjected to electrophoresis at a constant voltage of $100 \mathrm{~V}$ for $2 \mathrm{~h}$. The GIBCO BRL Benchmark prestained protein ladder provided markers of molecular weight. For Western blotting, proteins were electrotransferred to Immobilon-P membranes (Millipore) and immunoblotted (Craig et al. 1997) using rabbit antibody to CodY prepared by Biodesign International.

\section{Treatment of cells with decoyinine}

B. subtilis strains were grown in $\mathrm{S} 6$ medium (Freese et al. 1979b), supplemented with $50 \mu \mathrm{g}$ tryptophan per $\mathrm{mL}, 50 \mu \mathrm{g}$ phenylalanine per $\mathrm{mL}, 0.1 \% \mathrm{CAA}$, and $0.5 \%$ glucose (S6C medium). When the cells reached an optical density (600 nm) of 0.3 to 0.4 , decoyinine (dissolved in $1 \mathrm{~N} \mathrm{KOH}$ ) was added to a final concentration of $500 \mu \mathrm{g} / \mathrm{mL}$ to the appropriate cell cultures. An equivalent volume of $1 \mathrm{~N} \mathrm{KOH}$ was added to control cell cultures. At various time intervals after the addition of decoyinine, $0.5-1 \mathrm{~mL}$ samples were harvested and assayed for $\beta$-galactosidase activity as described by Slack et al. (1991). In some experiments, the cell cultures were incubated for $20 \mathrm{~h}$, and the sporulation efficiency of each strain was determined as the fraction of cells resistant to incubation for $10 \mathrm{~min}$ at $80^{\circ} \mathrm{C}$.

\section{Purification of 6x His-tagged CodY from B. subtilis}

B. subtilis strain $\mathrm{KWB} 1$ was grown in $4 \mathrm{~L}$ of DS medium to an $\mathrm{OD}_{600}$ of $\sim 1.0$ and harvested by centrifugation at $5000 \mathrm{rpm}$ and for $10 \mathrm{~min}$ at $4^{\circ} \mathrm{C}$. The cell pellets were washed with $15 \mathrm{~mL}$ of solution A (Serror and Sonenshein 1996a) supplemented with 1

Table 4. Bacillus subtilis strains used in this study

\begin{tabular}{|c|c|c|}
\hline Strain & Genotype & Source/reference \\
\hline FJS107 & $\operatorname{trp} C 2 S P \beta^{s}$ & Slack et al. 1993 \\
\hline JH642 & $\operatorname{trpC2}$ pheA1 & J.A. Hoch \\
\hline KWB1 & $\operatorname{trpC2}$ pheA1 codY ::pKW1 (cat) & JH642 X pKW1 \\
\hline MRLB10 & 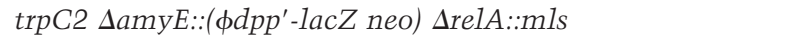 & PS59 X DNA TW30 \\
\hline PS29 & $\operatorname{trp} C 2$ gid::spc & Slack et al. 1995 \\
\hline PS37 & $\operatorname{trp} C 2$ gid::spc $\Delta \operatorname{cod} Y$ & Serror and Sonenshein $1996 \mathrm{~b}$ \\
\hline PS56 & $\operatorname{trp} C 2 \Delta a m y E::\left(\phi d p p^{\prime}-1 a c Z\right.$ neo) abrB:::cat::tet & P. Serror (unpub.) \\
\hline PS59 & $\operatorname{trpC2} \Delta a m y E::\left(\phi d p p^{\prime}-1 a c Z\right.$ neo) & FJS107 X DNA PS56 \\
\hline PS83 & $\operatorname{trp} C 2 \Delta a m y E::\left(\phi d p p^{\prime}-1 a c Z\right.$ neo) abrB::cat::tet gid::spc $\Delta c o d Y$ & PS56 X DNA PS37 \\
\hline PS164 & $\operatorname{trpC2} \Delta a m y E::\left(\phi d p p^{\prime}-1 a c Z\right.$ neo) gid::spc $\Delta \operatorname{cod} Y$ & PS37 X DNA PS56 \\
\hline TW30 & $\operatorname{trpC2}$ pheA1 $\Delta r e l A:: m l s$ & Wendrich and Marahiel 1997 \\
\hline
\end{tabular}


$\mathrm{mM}$ phenylmethylsulfonyl fluoride (PMSF) and stored at $-70^{\circ} \mathrm{C}$. The cell pellets were resuspended in $10 \mathrm{~mL}$ of buffer $\mathrm{S}(200 \mathrm{mM}$ $\mathrm{KCl}, 50 \mathrm{mM}$ Tris- $\mathrm{Cl}$ at $\mathrm{pH} 7.5,10 \%$ glycerol, $0.1 \%$ Nonidet P-40, 1 mM PMSF, $2 \mu$ M Pepstatin-A [PEP-A], 0.5 mM DTT, 0.2 mM EDTA) and passed three times through a French pressure cell at $12,000 \mathrm{psi}$. The cell lysates were then subjected to sonication using a Branson Sonifier Cell Disrupter 200 for 3 to 4 cycles of $30 \mathrm{sec}$ each, with 15 -sec rest periods between each cycle. The cleared lysates were centrifuged at 13,000 rpm for 20 min at $4^{\circ} \mathrm{C}$ to remove cell debris. The supernatant fluids were collected and genomic DNA and ribosomes were precipitated by the addition of streptomycin sulfate $(0.01 \mathrm{~g} / \mathrm{mL})$, with stirring for $10 \mathrm{~min}$ at $4^{\circ} \mathrm{C}$. The lysates were then centrifuged at $13,000 \mathrm{rpm}$ and for $15 \mathrm{~min}$ at $4^{\circ} \mathrm{C}$ and the supernatant fluids were dialyzed against $1 \mathrm{~L}$ of buffer $\mathrm{S}$ without DTT or EDTA for $1 \mathrm{~h}$ at $4^{\circ} \mathrm{C}$. Following a protocol provided by S. Gross, the dialysates were mixed with Talon (Clontech) metal $\left(\mathrm{Co}^{+}\right)$affinity resin (15 mL of cell lysate $/ 0.5 \mathrm{~mL}$ Talon) that had been equilibrated $\left(10 \mathrm{~min}\right.$ at $4^{\circ} \mathrm{C}$, with tumbling) with buffer I $(150 \mathrm{mM}$ $\mathrm{KCl}, 20 \mathrm{mM}$ Tris-Cl at $\mathrm{pH}$ 8.0, $5 \mathrm{mM} \beta$-mercaptoethanol, $10 \%$ glycerol, $1 \mathrm{mM}$ PMSF, $2 \mu \mathrm{M}$ PEP-A, $0.1 \%$ Nonidet P-40) and incubated for $20 \mathrm{~min}$ at $4^{\circ} \mathrm{C}$, with tumbling. The resin and bound protein were collected by centrifugation at $3000 \mathrm{rpm}$ for $3 \mathrm{~min}$ at $4^{\circ} \mathrm{C}$ and washed sequentially with $15 \mathrm{~mL}$ each of buffer I adjusted to $0.5 \mathrm{M} \mathrm{KCl}, 5 \mathrm{mM}$ imidazole and buffer I containing $125 \mathrm{mM} \mathrm{KCl}, 5 \mathrm{mM}$ imidazole. After loading the resin into a small column, proteins were eluted with buffer I containing 125 $\mathrm{mM} \mathrm{KCl}$ and $50-100 \mathrm{mM}$ imidazole. Fractions $(0.5 \mathrm{~mL})$ were collected and mixed with $5 \mu \mathrm{L}$ of $100 \mathrm{mM}$ DTT, and $100 \mathrm{mM}$ EDTA. All fractions were subjected to SDS-PAGE and the presence of CodY was determined by Western-blot analysis. Fractions found to contain CodY were pooled and in some cases dialyzed briefly against $2 \mathrm{~L}$ of solution $\mathrm{A}$ at $\mathrm{pH} 7.5$ (Serror and Sonenshein 1996a) at $4{ }^{\circ} \mathrm{C}$. The preparations of CodY-His 6 used here were typically $75 \%-85 \%$ pure.

\section{Ultraviolet-induced cross-linking of $\left[\alpha-{ }^{32} P\right]$ GTP to CodY}

One $\mu$ g of CodY protein $(3 \mu \mathrm{M})$ purified to near homogeneity from cell extracts of a CodY-overexpressing E. coli strain (Serror and Sonenshein 1996a) was incubated with $50 \mathrm{mM}$ Tris-Cl at $\mathrm{pH} 7.5,100 \mathrm{mM}$ KOAc, $0.1 \mathrm{mM}\left[\alpha_{-}{ }^{32} \mathrm{P}\right]$ GTP (NEN; $\left.3 \mu \mathrm{Ci} / \mathrm{nmol}\right)$ for $20 \mathrm{~min}$ on ice in a $10 \mu \mathrm{L}$-reaction volume. In some experiments, unlabelled nucleotides were included in the incubation. The reactions were then exposed to six cycles of UV light (1200 $\mathrm{J} / \mathrm{min}$ ) in a UV Stratalinker 1800 (Stratagene). Samples were immediately added to an equal volume of $2 \times$ SDS-PAGE loading buffer $(50 \mathrm{mM}$ Tris-Cl at pH 6.8, 2.5\% SDS, 0.1\% bromophenol blue, 10\% glycerol; Sambrook et al. 1989), incubated for $3 \mathrm{~min}$ at $80^{\circ} \mathrm{C}$, and then subjected to SDS-PAGE in a $12 \%$ denaturing polyacrylamide gel for $90 \mathrm{~min}$ at $100 \mathrm{~V}$. The gel was washed three times in distilled water (15 min per wash), dried, and exposed to Kodak X-OMAT AR film at $-70^{\circ} \mathrm{C}$ or to a PhosphorImager screen (Molecular Dynamics) overnight at room temperature.

\section{In vitro transcription}

DNA templates for in vitro runoff transcription were prepared by PCR amplification of pFS48 ( $d p p$; Slack et al. 1993) or pPH9 (veg; Le Grice et al. 1986). Promoter DNA (40 -80 nM) was incubated at $37^{\circ} \mathrm{C}$ in a $10-\mu l$ reaction containing $40 \mathrm{mM}$ Tris-Cl at $\mathrm{pH} 8.0,5 \mathrm{mM} \mathrm{MgCl}_{2}, 1 \mathrm{mM} \mathrm{MnCl}, 0.05 \mathrm{mM}$ EDTA at $\mathrm{pH}$ 8.0, $0.05 \mathrm{M} \mathrm{KCl}, 0.05 \mathrm{mg}$ BSA per $\mathrm{mL}, 2.5 \%$ glycerol, $0.2 \mathrm{mM}$ each of ATP, GTP, and CTP, $0.05 \mathrm{mM}\left[\alpha^{32} \mathrm{P}\right]$ UTP (NEN; 5 $\mu \mathrm{Ci} / \mathrm{nmol}$ ), 2U RNasin (Promega), 2 mM DTT, 19-37 nM $B$. subtilis RNA polymerase (Whipple and Sonenshein 1992) and varying amounts of CodY protein. After $15 \mathrm{~min}, 4 \mu \mathrm{L}$ of formamide-loading buffer (Sambrook et al. 1989) was added. After incubation for $10 \mathrm{~min}$ at $80^{\circ} \mathrm{C}$, samples $(5 \mu \mathrm{L})$ were subjected to polyacrylamide gel electrophoresis on an $8 \mathrm{M}$ urea/5\% polyacrylamide gel in TBE (0.09 M Tris-borate, $0.002 \mathrm{M}$ EDTA at $\mathrm{pH}$ 8.0). The dried gel was exposed to a PhosphorImager screen overnight. The expected runoff transcripts for $d p p$ and veg are $155 \mathrm{n}$ and $104 \mathrm{n}$, respectively.

\section{Acknowledgments}

We thank B. Belitsky, D. RayChaudhuri, C. Squires, and A. Wright for their critical reading; S. Gross for sharing his Histagged protein-purification protocol; C. Delorme and colleagues for allowing us to cite their unpublished results; and T.M. Wendrich and M.A. Marahiel for providing strain TW30. We are very grateful to D. RayChaudhuri and A. Wright for their expert advice and to N. Mani for help with the in vitro transcription assays. This work was supported by U.S. Public Health Service research grant GM42219.

The publication costs of this article were defrayed in part by payment of page charges. This article must therefore be hereby marked "advertisement" in accordance with 18 USC section 1734 solely to indicate this fact.

\section{References}

Altschul, F., Madden, T.L., Schäffer, A.A., Zhang, J., Zhang, Z., Miller, W., and Lipman, D.J. 1997. Gapped BLAST and PSIBLAST: A new generation of protein database search programs. Nucleic Acids Res. 25: 3389-3402.

Atkinson, M.R., Wray, L.V., and Fisher, S.H. 1990. Regulation of histidine and proline degradation enzymes by amino acid availability in Bacillus subtilis. J. Bacteriol. 172: 47584765.

Bai, U., Mandic-Mulec, I., and Smith, I. 1993. SinI modulates the activity of SinR, a developmental switch protein of $B a$ cillus subtilis, by protein-protein interaction. Genes \& Dev. 7: 139-148.

Bolotin A., Mauger, S., Malarme, K., Ehrlich, S.D., and Sorokin, A. 1999. Low-redundancy sequencing of the entire Lactococcus lactis IL403 genome. Antonie Van Leeuwenhoek 76: 2776.

Bourne, H.R., Sanders, D.A., and McCormick, F. 1991. The GTPase superfamily: Conserved structure and molecular mechanism. Nature 349: 117-127.

Burkholder, W.F. and Grossman, A.D. 2000. Regulation of the initiation of endospore formation in Bacillus subtilis. In Prokaryotic development (eds. Y. Brun and L. Shimkets), pp. 151-166. ASM Press, Washington, D.C.

Cashel, M., Gentry, D., Hernandez, V., and Vinella, D. 1996. The stringent response. In Escherichia coli and Salmonella (eds. F. Neidhardt et al.), pp. 1458-1496. ASM Press, Washington, D.C.

Cervin, M.A., Lewis, R.J., Brannigan, J.A., and Spiegelman, G.B. 1998. The Bacillus subtilis regulator SinR inhibits spoIIG promoter transcription in vitro without displacing RNA polymerase. Nucleic Acids Res. 26: 3806-3812.

Craig, J.E., Ford, M.J., Blaydon, D.C., and Sonenshein, A.L. 1997. A null mutation in the Bacillus subtilis aconitase gene 
causes a block in Spo0A-phosphate-dependent gene expression. J. Bacteriol. 179: 7351-7359.

Debarbouille, M., Gardan, R., Arnaud, M., and Rapoport, G. 1999. Role of $b k d R$, a transcriptional activator of the sigLdependent isoleucine and valine degradation pathway in $\mathrm{Ba}$ cillus subtilis. J. Bacteriol. 181: 2059-2066.

Dingman, D.W., Rosenkrantz, M.S., and Sonenshein, A.L. 1987. Relationship between aconitase gene expression and sporulation in Bacillus subtilis. J. Bacteriol. 169: 3068-3075.

Eymann, C., Mittenhuber, G., and Hecker, M. 2001. The stringent response, $\sigma^{\mathrm{H}}$-dependent gene expression and sporulation in Bacillus subtilis. Mol. Gen. Genet. 264: 913-931.

Ferson, A.E., Wray Jr., L.V., and Fisher, S.H. 1996. Expression of the Bacillus subtilis gabP gene is regulated independently in response to nitrogen and amino acid availability. Mol. Microbiol. 22: 693-701.

Fisher, S.H., Rohrer, K., and Ferson, A.E. 1996. Role of CodY in regulation of the Bacillus subtilis hut operon. J. Bacteriol. 178: $3779-3784$.

Fouet, A. and Sonenshein, A.L. 1990. A target for carbon sourcedependent negative regulation of the citB promoter of Bacillus subtilis. J. Bacteriol. 172: 835-844.

Freese, E., Heinze, J.E., and Galliers, E.M. 1979a. Partial purine deprivation causes sporulation of Bacillus subtilis in the presence of excess ammonia, glucose, and phophate. J. Gen. Microbiol. 115: 193-205.

Freese, E.B., Vasantha, N., and Freese, E. 1979b. Induction of sporulation in developmental mutants in Bacillus subtilis. Mol. Gen. Genet. 170: 67-74.

Gaal, T., Bartlett, M.S., Ross, W., Turnbough, C.L., Jr., and Gourse, R.L. 1997. Transcription regulation by initiating NTP concentration: rRNA synthesis in bacteria. Science 278: 2092-2097.

Guédon, E., Serror, P., Ehrlich, S.D., Renault, P., and Delorme, C. 2001. Pleiotropic transcriptional repressor CodY senses the intracellular pool of branched chain amino acids in Lactococcus lactis Mol. Microbiol. (in press).

Kok, J., Trach, K.A., and Hoch, J.A. 1994. Effects on Bacillus subtilis of a conditional lethal mutation in the essential GTP-binding protein Obg. J. Bacteriol. 176: 7155-7160.

Lazazzera, B.A., Kurtser, I.G., McQuade, R.S., and Grossman, A.D. 1999. An autoregulatory circuit affecting peptide signaling in Bacillus subtilis. J. Bacteriol. 181: 5193-5200.

Le Grice, S.F., Shih, C.C., Whipple, F., and Sonenshein, A.L. 1986. Separation and analysis of the RNA polymerase binding sites of a complex Bacillus subtilis promoter. Mol. Gen. Genet. 204: 229-236.

Lopez, J., Marks, C., and Freese, E. 1979. The decrease in guanine nucleotides initiates sporulation in Bacillus subtilis. Biochim. Biophys. Acta 587: 238-252.

Lopez, J.M., Dromerick, A., and Freese, E. 1981. Response of guanosine 5 '-triphopshate concentration to nutritional changes and its significance for Bacillus subtilis sporulation. J. Bacteriol. 146: 605-613.

Mathiopoulos, C., Mueller, J.P., Slack, F.J., Murphy, C.G., Patankar, S., Bukusoglu, G., and Sonenshein, A.L. 1991. A Bacillus subtilis dipeptide transport system expressed early during sporulation. Mol. Microbiol. 5: 1903-1913.

Mirel, D.B., Estacio, W.F., Mathieu, M., Olmsted, E., Ramirez, J., and Marquez-Magana, L.M. 2000. Environmental regulation of Bacillus subtilis sigma(D)-dependent gene expression. J. Bacteriol. 182: 3055-3062.

Mitani, T., Heinze, J., and Freese, E. 1977. Induction of sporulation in Bacillus subtilis by decoyinine or hadacidin. Biochim. Biophys. Acta 77: 1118-1125.

Mueller, J.P., Bukusoglu, G., and Sonenshein, A.L. 1992 Tran- scriptional regulation of Bacillus subtilis glucose starvationinducible genes: Control of gsiA by the ComP-ComA signal transduction system. J. Bacteriol. 174: 4361-4373.

Neidhardt, F., Ingraham, J., and Schaechter, M. 1990. Physiology of the bacterial cell. A molecular approach. p. 98. Sinauer Associates, Inc., Sunderland, Massachusetts.

Nygaard, P. 1993. Purine and pyrimidine salvage pathways. In Bacillus subtilis and other gram-positive bacteria (eds. A.L. Sonenshein et al.), pp. 359-378. American Society of Microbiology, Washington, D.C.

Ochi, K., Kandala, J., and Freese, E. 1981. Initiation of Bacillus subtilis sporulation by the stringent reponse to partial amino acid deprivation. I. Biol. Chem. 256: 6866-6875.

Quisel, J.D., Lin, D.C., and Grossman, A.D. 1999. Control of development by altered localization of a transcription factor in B. subtilis. Mol. Cell 4: 665-672.

Ratnayake-Lecamwasam, M. 2001. "Synthesis and regulation of CodY, a nutrient-sensitive repressor of early stationary phase genes, in Bacillus subtilis." Ph.D. thesis, Tufts University, Medford, Massachusetts.

RayChaudhuri, D. and Park, J.T. 1992. Escherichia coli celldivision gene $f t s Z$ encodes a novel GTP-binding protein. $\mathrm{Na}$ ture 359: 251-254.

Sambrook, J., Fritsch, E., and Maniatis, T. 1989. Molecular cloning. A laboratory manual. Cold Spring Harbor Laboratory Press, Cold Spring Harbor, NY.

Saraste, M., Sibbald, P.R., and Wittinghofer, A. 1990. The Ploop-A common motif in ATP- and GTP-binding proteins. Trends Biochem. Sci.15: 430-434.

Scott, J.M., Ju, J., Mitchell, T., and Haldenwang, W.G. 2000. The Bacillus subtilis GTP binding protein Obg and regulators of the sigma(B) stress response transcription factor cofractionate with ribosomes. J. Bacteriol. 182: 2771-2777.

Serror, P. and Sonenshein, A.L. 1996a. Interaction of CodY, a novel Bacillus subtilis DNA-binding protein, with the $d p p$ promoter region. Mol. Microbiol. 20: 843-852.

- 1996b. CodY is required for nutritional repression of Bacillus subtilis genetic competence. I. Bacteriol. 178: 5910-5915.

Singer, M. and Kaiser, D. 1995. Ectopic production of guanosine penta- and tetraphosphate can initiate early developmental gene expression in Myxococcus xanthus. Genes \& Dev. 9: 1633-1644.

Slack, F.J., Mueller, J.P., Strauch, M.A., Mathiopoulos, C., and Sonenshein, A.L. 1991. Transcriptional regulation of a Bacillus subtilis dipeptide transport operon. Mol. Microbiol. 5: 1915-1925.

Slack, F., Mueller, J., and Sonenshein, A.L. 1993. Mutations that relieve nutritional repression of the Bacillus subtilis dipeptide permease operon. J. Bacteriol. 175: 4605-4614.

Slack, F., Serror, P., Joyce, E., and Sonenshein, A.L. 1995. A gene required for nutritional repression of the Bacillus subtilis dipeptide permease operon. Mol. Microbiol. 15: 689-702.

Sonenshein, A.L. 1989. Metabolic regulation of sporulation and other stationary-phase phenomena. In Regulation of prokaryotic development (eds. I. Smith et al.), pp. 109-130. Am. Soc. Microb. Press, Washington, D.C.

. 2000. Endospore-forming bacteria: An overview. In Prokaryotic development (eds. Y. Brun and L. Shimkets), pp. 133-150. ASM Press, Washington, D.C.

Speck, C., Weigel, C., and Messer, W. 1999. ATP- and ADPDnaA protein, a molecular switch in gene regulation. EMBO J. 18: 6169-6176.

Strauch, M.A. 1993. Regulation of Bacillus subtilis gene expression during transition from exponential growth to stationary phase. Prog. Nucleic Acids Res. Mol. Biol. 46: 121-153. 
Trach, K. and Hoch, J.A. 1989. The Bacillus subtilis spoOB stage 0 sporulation operon encodes an essential GTP-binding protein. J. Bacteriol. 171: 1362-1371.

Vidwans, S.J., Ireton, K., and Grossman, A.D. 1995. Possible role for the essential GTP-binding protein Obg in regulating the initiation of sporulation in Bacillus subtilis. J. Bacteriol. 177: 3308-3311.

Wendrich, T.M. and Marahiel, M.A. 1997. Cloning and characterization of a relA/spoT homologue from Bacillus subtilis. Mol. Microbiol. 26: 65-79.

Whipple, F.W. and Sonenshein, A.L. 1992. Mechanism of initiation of transcription by $B$. subtilis RNA polymerase at several promoters. J. Mol. Biol. 223: 399-414.

Wray, Jr., L.V., Ferson, A.E., and Fisher, S.H. 1997. Expression of the Bacillus subtilis ure $A B C$ operon is controlled by multiple regulatory factors including CodY, GlnR, TnrA, and Spo0H. J. Bacteriol. 179: 5494-5501. 


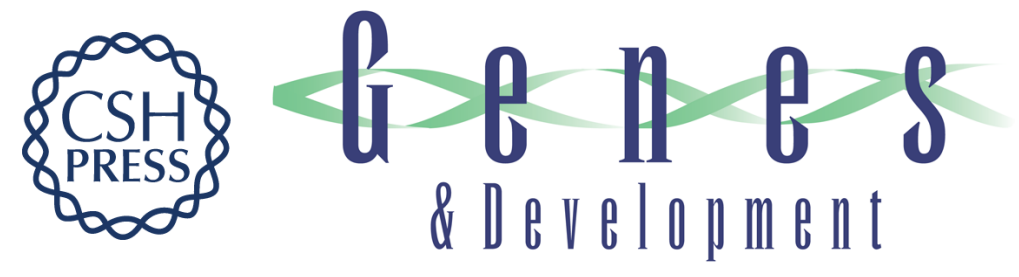

\section{Bacillus subtilis CodY represses early-stationary-phase genes by sensing GTP levels}

Manoja Ratnayake-Lecamwasam, Pascale Serror, Ka-Wing Wong, et al.

Genes Dev. 2001, 15:

Access the most recent version at doi:10.1101/gad.874201

References This article cites 43 articles, 22 of which can be accessed free at: http://genesdev.cshlp.org/content/15/9/1093.full.html\#ref-list-1

License

Email Alerting

Receive free email alerts when new articles cite this article - sign up in the box at the top Service right corner of the article or click here.

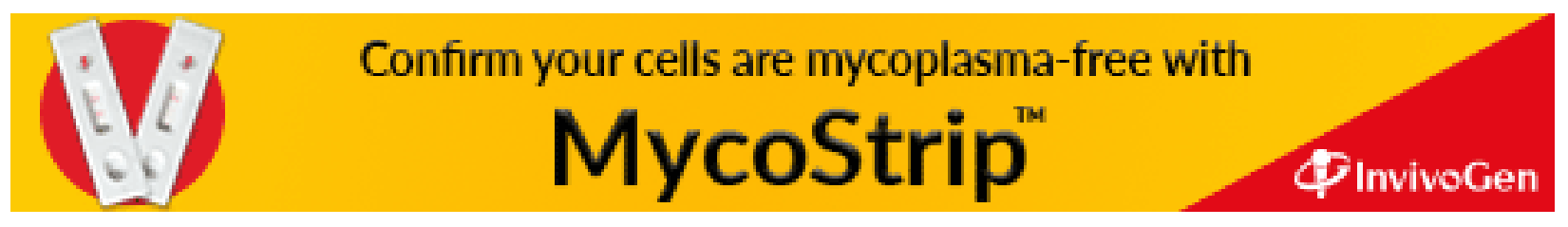

